\title{
EBV-1 and HCMV in aggressive periodontitis in Brazilian patients
}

\author{
EBV-1 e HCMV na periodontite agressiva em \\ pacientes brasileiros
}

\begin{abstract}
Soraia Almeida Watanabe $e^{(a)}$ Jeane de Fátima Correia-Silva(a) Martinho Campolina Rebello Horta(b) José Eustáquio da Costa(a) Ricardo Santiago Gomez ${ }^{(a)}$
\end{abstract}

(a) MScs, Department of Oral Surgery and Pathology, School of Dentistry, Federal University of Minas Gerais.

(b) PhD, School of Dentistry, Pontifical Catholic University of Minas Gerais.

\section{Corresponding author:}

Ricardo Santiago Gomez

Faculdade de Odontologia da UFMG

Depto. de Clínica, Patologia e Cirurgia

Av. Antonio Carlos, 6627

Belo Horizonte - MG - Brazil

CEP: 31270-901

E-mail:rsgomez@ufmg.br

Received for publication on Aug 21, 2006

Sent for alterations on Oct 04, 2006

Accepted for publication on Mar 03, 2007

\begin{abstract}
The purpose of the present investigation was to compare the presence of Epstein-Barr virus type 1 (EBV-1) and of Human Cytomegalovirus (HCMV) in crevicular fluid samples from deep and shallow periodontal pocket sites of Brazilian patients with aggressive periodontitis. A total of 30 systemically healthy patients with aggressive periodontitis participated in the study. Paper points were inserted into 2 gingivitis sites $(\leq 3 \mathrm{~mm})$ and into 2 periodontitis sites $(\geq 5 \mathrm{~mm})$ in each patient. PCR assay was used to identify genomic copies of HCMV and EBV-1. Twenty-three patients (77\%) were positive for EBV-1, while only 2 patients $(6 \%)$ were positive for HCMV. The McNemar test revealed a positive association between EBV-1 and periodontal lesions ( $p=0.043)$. Thirtyfour $(57 \%)$ out of 60 periodontitis sites were positive for EBV-1, whereas $18(30 \%)$ gingivitis sites were positive $(\mathrm{p}=0.01)$. Only two sites $(6.7 \%)$ were positive for HCMV. No positive association was found between HCMV and periodontitis or gingivitis $(p=0.479)$. The elevated occurrence of EBV-1 DNA in periodontal pockets of patients with aggressive periodontitis supports a possible periodontopathic role of this virus.
\end{abstract}

Descriptors: Epstein-Barr virus; Cytomegalovirus; Periodontitis.

Resumo: O objetivo do presente estudo foi comparar a presença do vírus Epstein-Barr tipo 1 (EBV-1) e do Citomegalovírus Humano (HCMV) em amostras de fluido crevicular de bolsas periodontais rasas e profundas de pacientes brasileiros com periodontite agressiva. Trinta pacientes sistemicamente saudáveis com periodontite agressiva participaram deste estudo. Cones de papel foram inseridos em 2 sítios de gengivite $(\leq 3 \mathrm{~mm})$ e em 2 sítios de periodontite $(\geq 5 \mathrm{~mm}$ ) de cada paciente. Reações de PCR foram usadas para identificar cópias de DNA genômico de HCMV e EBV-1. Em 23 pacientes (77\%), os testes foram positivos para EBV-1, enquanto apenas 2 pacientes $(6 \%)$ foram positivos para HCMV. O teste de McNemar apontou associação positiva entre EBV-1 e lesões periodontais $(\mathrm{p}=0,043)$. Trinta e quatro $(57 \%)$ dos 60 sítios de periodontites foram positivos para o EBV-1, enquanto 18 (30\%) dos sítios de gengivites foram positivos ( $\mathrm{p}=0,01)$. Apenas 2 sítios $(6,7 \%)$ foram positivos para o HCMV. Não foi encontrada associação positiva entre HCMV e periodontite ou gengivite $(\mathrm{p}=0,479)$. A alta ocorrência de DNA de EBV-1 em bolsas periodontais de pacientes com periodontite agressiva corrobora a possível função periodontopática deste vírus.

Descritores: Herpesvirus 4 humano; Citomegalovírus; Periodontite. 


\section{Introduction}

Little is known about the conversion of gingivitis sites into periodontitis sites ${ }^{21}$ or why periodontal tissue breakdown progresses in a localized and bilaterally symmetrical pattern. ${ }^{4,15}$ Many studies have suggested that the coexistence of periodontal herpesviruses, periodontopathic bacteria and the local host immune response are involved in periodontal disease evolution. ${ }^{3,6,10,12,19,20}$

The association of herpesviruses with oral disease is not a novel issue. EBV is closely related to Burkitt's lymphoma, nasopharyngeal carcinoma and hairy leukoplakia. ${ }^{8}$ More recently, the HCMV has been associated with periodontal abscesses. ${ }^{20}$

Genomes of two types of herpesviruses, HCMV and EBV, occur at high frequency in progressive periodontitis in adults, ${ }^{12,27}$ localized $^{24}$ and generalized aggressive periodontitis, ${ }^{12,20,24} \mathrm{HIV}$-periodontitis, ${ }^{4,24}$ acute necrotizing gingivitis, ${ }^{3}$ periodontal abscesses, ${ }^{20}$ Pappilon Lefrève periodontitis ${ }^{26}$ and 21 trisomic periodontitis. ${ }^{9}$ Rones et al. ${ }^{18}$ (1983) demonstrated a significant positivity of both epithelial and fibroblast cells from the gingival sulcus area for the herpes simplex virus in vitro, suggesting that those cells could be a reservoir for the latent virus. The involvement of herpesviruses in the etiology of periodontal disease was suggested by its presence in gingival tissue, gingival crevicular fluid and subgingival plaque affected by periodontal disease. ${ }^{6}$ However, the role of HCMV and EBV-1 in periodontal disease pathogenesis remains to be elucidated.

The purpose of the present investigation was to compare the presence of genomic sequences of HCMV and EBV-1 in crevicular fluid samples from deep and shallow periodontal pockets sites of Brazilian patients with aggressive periodontitis.

\section{Material and Methods Patients}

The study included 30 individuals with aggressive periodontitis (18 females, 12 males) aged 18 to 45 years (mean age: 32.4 years). Subjects were recruited at the Periodontics Clinic, School of Dentistry, Federal University of Minas Gerais, MG, Brazil. Inclusion factors were, according to Tonetti, Mombelli ${ }^{25}$ : Patients who were clinically healthy, present- ing rapid attachment loss and bone destruction and family aggregation. We included patients who were older than 35 years of age only when they presented the three common features of aggressive periodontitis. Indeed, according to Tonetti, Mombelli ${ }^{25}$ (1999), this form of disease can occur at any age and is not necessarily confined to individuals under the arbitrarily chosen age of 35 . Subjects who had received antibiotics for at least 6 months prior to the study were excluded from the examination. Nineteen out of 30 patients were not submitted to any kind of periodontal treatment before sample collection. The study protocol was approved by the local Ethics Committee. Informed consent was obtained from all the subjects.

\section{Sample collection preparation}

Sample collection was obtained from each patient from the 2 deepest periodontal sites of the dentition with probing depth (PD) $\geq 5 \mathrm{~mm}$ and clinical attachment level $\geq 4 \mathrm{~mm}$ and from 2 gingivitis sites with $\mathrm{PD} \leq 3 \mathrm{~mm}$, bleeding upon probing and clinical absence of attachment and bone loss. Probing depth was defined as the distance from the gingival margin to the most apical probing depth of the gingival/periodontal pocket and was rounded to the nearest higher millimeter.

All sample sites exhibited gingival inflammation and bleeding upon sampling. One examiner performed these clinical procedures. Into each gingival/periodontal pocket a sterile fine paper point was inserted for 30 seconds. After being immediately suspended in $400 \mathrm{ml}$ Krebs buffer $(20 \%$ $\mathrm{NaCl}, 2 \% \mathrm{KCl}, 2 \% \mathrm{CaCl}_{2} 2 \mathrm{H}_{2} \mathrm{O}, \mathrm{MgSO}_{4}, \mathrm{KH}_{2} \mathrm{PO}_{4}$, $\mathrm{C}_{6} \mathrm{H}_{12} \mathrm{O}_{6}$ ), the pellet was subjected to $10 \mathrm{~min}$ of centrifugation at $10 \mathrm{~g}$, being thereafter stored at $-20^{\circ} \mathrm{C}$ until processing. The DNA extraction was carried out as described by Boom et al. ${ }^{2}$ (1990) and stored at $-20^{\circ} \mathrm{C}$.

EBV DNA was identified by PCR with the EBV primers that amplified a sequence of the EBNA1 gene. ${ }^{23}$ A nested PCR method was used to identify viral DNA of Cytomegalovirus. Primers for identifying HCMV DNA amplified a sequence of the glycoprotein $\mathrm{B}(\mathrm{gB})$ gene. ${ }^{26}$ The human $\beta$-globin gene was used as an internal control. ${ }^{7}$ 
PCR amplification was performed in a thermal cycler (Gene Amp. PCR System 2400) (Eppendorf, Westbury, NY, USA), and included an initial denaturation, followed by cycles of denaturation, primer annealing, and an extension, ending with a final extension (Table 1). Positive and negative (PCR reagents without DNA) controls were routinely included. PCR for HCMV was carried out in a $25 \mu \mathrm{l}$ mixture containing Taq DNA polymerase (1 unit/reaction) (Phoneutria, Belo Horizonte, MG, Brazil), PCR buffer $(40 \mathrm{mM} \mathrm{NaCl}, 10 \mathrm{mM}$ Tris- $\mathrm{Cl} \mathrm{pH} 8.4$, $2.5 \mathrm{mM} \mathrm{MgCl} 2), 0.1 \mathrm{mM}$ deoxynucleosidetriphosphates (Amersham Biosciences, Buckinghamshire, UK), $10 \mathrm{pmol} /$ reaction primers and genomic DNA. After PCR, $2 \mathrm{ml}$ of the final product were transferred to the reaction mixture of the second PCR and reamplified with the inner pair of primers. For identification of EBV-DNA, a mixture of $25 \mu \mathrm{l}$ containing Taq DNA polymerase (1 unit/reaction), PCR buffer $\left(10 \mathrm{mM}\left(\mathrm{NH}_{4}\right)_{2} \mathrm{SO}_{4}, 10 \mathrm{mM} \mathrm{KCl}, 10 \mathrm{mM}\right.$ Tris- $\mathrm{Cl} \mathrm{pH} 8.4,3.0 \mathrm{mM} \mathrm{MgCl}_{2}$ ), $0.1 \mathrm{mM}$ deoxynucleosidetriphosphates, $10 \mathrm{pmol} /$ reaction primers and genomic DNA was used. Primers and PCR conditions are shown in Table 1.

\section{Electrophoresis}

HCMV PCR products were visualized with UV light as a single band (224 bp) by staining with ethidium bromide after $1.5 \%$ agarose gel electrophoresis. The EBV amplified products (269 bp) were visualized by $6.5 \%$ polyacrilamide gel electrophoresis and silver stained.

\section{Statistical analysis}

Differences in viral prevalence between gingivitis sites and periodontal pockets within the same subject were determined using the McNemar test. Chisquare and Exact Fisher's tests were used to test the independent samples. $p$ values equal to or less than 0.05 were considered statistically significant.

\section{Results}

The distribution of patients according to the presence of EBV-1 in gingivitis and periodontitis sites is shown in Table 2. Patients that showed the presence of EBV-1 in at least one gingivitis or periodontitis site were considered positive. Twenty-three out of $30(77 \%)$ patients demonstrated the presence of EBV-1 DNA. Ten patients presented simultaneously positive periodontitis sites and negative gingivitis sites for EBV-1. In addition, only two patients presented positive gingivitis sites together with negative periodontitis sites for this virus. The McNemar test revealed a positive association between EBV-1 and periodontitis lesions $(\mathrm{p}=0.043)$.

The distribution of gingivitis and periodontitis sites according to the presence of EBV-1 is shown in Table 3. EBV-1 DNA was identified in $52(43 \%)$ gingivitis and periodontitis sites (Table 3). Thirty-four $(57 \%)$ out of 60 periodontitis sites were positive for EBV-1, whereas 18 (30\%) gingivitis sites were positive for the same virus. The difference between periodontitis sites and gingivitis sites according to the presence of EBV-1 was statistically significant $(p=0.0057)$. The periodontitis sites showed an in-

Table 1 - Primers and PCR conditions.

\begin{tabular}{|c|c|c|c|c|}
\hline & Virus & Primer Pair & PCR program & Product size \\
\hline \multirow{4}{*}{ HCMV } & \multirow{2}{*}{ Outer primers } & F:5'ACAT GGAATCCAGGATCTGGTGCC 3' & \multirow{2}{*}{$\begin{array}{c}95^{\circ} \mathrm{C} / 30 \mathrm{~s} ; 58^{\circ} \mathrm{C} / 54 \mathrm{~s} \\
30 \text { cycles; } 72^{\circ} \mathrm{C} / 30 \mathrm{~s}\end{array}$} & \multirow{2}{*}{$612 \mathrm{bp}$} \\
\hline & & R:5' CCTATGATATGCCACGAAAACCG 3' & & \\
\hline & \multirow{2}{*}{ Inner primers } & F: 3’ CAACACGTAACGTCTTCTGAAGCC 5' & \multirow{2}{*}{$\begin{array}{l}95^{\circ} \mathrm{C} / 30 \mathrm{~s} ; 57^{\circ} \mathrm{C} / 45 \mathrm{~s} \\
30 \text { cycles; } 72^{\circ} \mathrm{C} / 30 \mathrm{~s}\end{array}$} & \multirow{2}{*}{$224 \mathrm{bp}$} \\
\hline & & R: 5' TAG ACCACCATGATGCCCTCATCC 3' & & \\
\hline \multirow{2}{*}{\multicolumn{2}{|c|}{ EBV-1 }} & F:5’ GTCATCATCATCCGGGTCTC 3’ & \multirow{2}{*}{$\begin{array}{c}94^{\circ} \mathrm{C} / 60 \mathrm{~s} ; 56^{\circ} \mathrm{C} / 50 \mathrm{~s} \\
40 \text { cycles; } 72^{\circ} \mathrm{C} / 60 \mathrm{~s}\end{array}$} & \multirow{2}{*}{$269 \mathrm{bp}$} \\
\hline & & R:5' TTCGGGTTGGAACCTCCTTG 3' & & \\
\hline \multirow{2}{*}{\multicolumn{2}{|c|}{$\beta$-globin }} & $\mathrm{F}: 5^{\prime}$ CCACTTCATCCACGTTCACC 3' & \multirow{2}{*}{$\begin{array}{c}94^{\circ} \mathrm{C} / 45 \mathrm{~s} ; 56^{\circ} \mathrm{C} / 30 \mathrm{~s} \\
35 \text { cycles; } 72^{\circ} \mathrm{C} / 30 \mathrm{~s}\end{array}$} & \multirow{2}{*}{$268 \mathrm{bp}$} \\
\hline & & R: 5' GAAGAGCCAAGGACAGGT AC 3' & & \\
\hline
\end{tabular}

$F=$ forward primer, $R=$ reward primer. 
Table 2 - Distribution of patients according to the presence of EBV-1 in gingivitis and periodontitis sites.

\begin{tabular}{l|c|c}
\hline & $\begin{array}{c}\text { EBV-1 + } \\
\text { periodontitis sites }\end{array}$ & $\begin{array}{c}\text { EBV-1 - } \\
\text { periodontitis sites }\end{array}$ \\
\hline EBV + gingivitis sites & 11 & 2 \\
\hline EBV - gingivitis sites & 10 & 7 \\
\hline
\end{tabular}

McNemar Test, $p=0.0433$. *Patients that showed the presence of EBV-1 in at least one gingivitis or periodontitis site were considered positive.

Table 3 - Distribution of gingivitis and periodontitis sites according to the presence of EBV-1.

\begin{tabular}{l|c|c}
\hline & EBV-1 + & EBV-1 - \\
\hline Gingivitis sites & 18 & 42 \\
\hline Periodontitis sites & 34 & 26 \\
\hline \multicolumn{2}{l}{ Chi square test $p=0.0057$. Odds ratio: $3.05,95 \% \mathrm{Cl}: 1.43-6.47}$.
\end{tabular}

creased prevalence of EBV-1 compared with the gingivites sites (OR: 3.05, 95\% CI: 1.43-6.47).

The male patients presented more positive sites for EBV-1 than female patients in both groups, gingivitis $(\mathrm{p}=0.027)$ and periodontitis $(\mathrm{p}=0.025)$, as shown in Table 4.

No significant association was observed between the prevalence of EBV-1 and age $(\mathrm{p}=0.371)$. The presence of HCMV and EBV-1 was not associated with a previous history of periodontal treatment before samples' collection $(\mathrm{p}=0.151)$.

HCMV DNA was found in only $2(6 \%)$ patients. Two sites $(6.7 \%)$ were positive for HCMV: one positive sample occurred in a gingivitis site and the other occurred in a periodontitis site. No positive association was found between HCMV and periodontitis or gingivitis $(\mathrm{p}=0.479)$. Only one site exhibited both viruses.

\section{Discussion}

In a model for herpesviruses-related periodontitis, Slots, Contreras ${ }^{22}$ (2000) depicted that herpesvirus infection of periodontal sites may be important in a multistage pathogenesis by altering local host responses. Initially, bacterial infection of the gingiva causes inflammatory cells to enter the gingival tissue, with periodontal macrophages and T-lymphocytes harboring latent EBV. Reactivation of herpes-
Table 4 - Distribution of negative and positive samples for EBV-1 according to gender.

\begin{tabular}{|c|c|c|c|c|}
\hline & & EBV-1 + & EBV-1 - & $\mathrm{p}$ values \\
\hline \multirow{2}{*}{ Both sites } & Male & 9 & 2 & \multirow{2}{*}{$p=0.685$} \\
\hline & Female & 14 & 5 & \\
\hline \multirow{2}{*}{ Gingivitis sites } & Male & 8 & 3 & \multirow{2}{*}{$p=0.027$} \\
\hline & Female & 5 & 14 & \\
\hline \multirow{2}{*}{ Periodontitis sites } & Male & 9 & 2 & \multirow{2}{*}{$p=0.025$} \\
\hline & Female & 7 & 12 & \\
\hline
\end{tabular}

Fisher's test.

viruses from latency may occur spontaneously or during periods of impaired host defense, resulting from immunosuppression, infection, physical trauma, hormonal changes, etc. Herpesvirus activating factors are also risk factors/indicators for periodontal disease. ${ }^{16}$

Contreras et al. ${ }^{3}$ (1997) demonstrated an increased occurrence of suspected periodontal pathogens in periodontal sites showing HCMV or EBV. A shift from latent to active virus infection of the periodontium might partly explain subgingival overgrowth of some periodontal pathogens and the burst-like pattern of periodontal breakdown. Indeed, Contreras et al. ${ }^{6}$ (1999) demonstrated an association between HCMV and EBV-1 and an increased occurrence of various pathogenic periodontal bacteria.

To cope with hostile host environments, herpesviruses have developed strategies to down-regulate anti-viral host defenses to suit their replication needs. Herpesviruses aim to destroy components of the major histocompatibility complex pathways within macrophages, markedly impairing their principal role in antigen presentation, silence natural killer cells, inhibit apoptosis, and divert potent cytokine responses. ${ }^{1}$

In the present study, we found a significantly higher occurrence of EBV-1 in periodontal sites than in gingivitis sites. The higher occurrence of EBV-1 in deep periodontal sites than in gingivitis sites is consistent with the herpesviruses playing a role in the pathogenesis of periodontitis. The male patients presented more positive sites for EBV-1 than female patients. In contrast to our results, a previous investigation dem- 
onstrated that the presence of EBV-1 was equally distributed between men and women. ${ }^{13}$ It's possible that boys usually initiate their sexual relationships earlier than girls, a fact that could have increased EBV-1 infection prevalence in male patients. Population size or ethnic differences may account for this variation. Our results demonstrated that the presence of EBV-1 showed no age predilection, confirming other previous studies. ${ }^{13,24}$ Some investigators have suggested that once EBV-1 is present (or active), its herpesvirusmediated impairment of the host defense may give rise to subgingival growth of periodontal pathogens and subsequent periodontal attachment loss. ${ }^{6,9,11}$

Some studies have associated the presence of

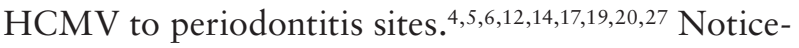
ably, our results of this experiment showed no statistical relationship between HCMV and periodontitis. This discrepancy may also be due to sample size, selection of the subjects evaluated, or ethnic differences. The absence of HCMV DNA could de-

\section{References}

1. Boeckh M, Nichols WG. Immunosuppressive effects of betaherpesviruses. Herpes. 2003;10(1):12-6.

2. Boom R, Sol CJ, Salimans MM, Jansen CL, Wertheim-van Dillen PM, van der Noordaa J. Rapid and simple method for purification of nucleic acids. J Clin Microbiol. 1990;28(3):495503.

3. Contreras A, Falkler WA Jr, Enwonwu CO, Idigbe EO, Savage $\mathrm{KO}$, Afolabi $\mathrm{MB}$ et al. Human herpesviridae in acute necrotizing ulcerative gingivitis in children in Nigeria. Oral Microbiol Immunol. 1997;12(5):259-65.

4. Contreras A, Nowzari H, Slots J. Herpesviruses in periodontal pocket and gingival tissue specimens. Oral Microbiol Immunol. 2000;15(1):15-8.

5. Contreras A, Slots J. Active cytomegalovirus infection in human periodontitis. Oral Microbiol Immunol. 1998;13(4):22530.

6. Contreras A, Umeda M, Chen C, Bakker I, Morrison JL, Slots $\mathrm{J}$. Relationship between herpesviruses and adult periodontitis and periodontopathic bacteria. J Periodontol. 1999;70(5):47884.

7. Gall-Troselj K, Mravak-Stipetic M, Jurak I, Ragland Wl, Pavelic J. Helicobacter pylori colonization of tongue mucosa - increased incidence in atrophic glossitis and burning mouth syndrome (BMS). J Oral Pathol Med. 2001;30(9):5603. note the stability of periodontitis sites in the sample, since a previous study observed a higher frequency of HCMV in progressing periodontitis sites compared to that of stable sites. ${ }^{10}$

\section{Conclusions}

In conclusion, in the current study, EBV-1 was more frequently detected in periodontitis sites than in gingivitis sites from periodontitis patients. The elevated occurrence of EBV-1 DNA in periodontal pockets of periodontitis lesions in patients with aggressive periodontitis supports a possible periodontopathic role of this virus.

\section{Acknowledgements}

This study was supported by grants from the National Council for Scientific and Technological Development (CNPq) and the State of Minas Gerais Research Foundation (FAPEMIG), Brazil. Dr. RS Gomez is a research fellow of the CNPq.

8. Greenspan D, De Villiers EM, Greenspan JS, De Souza YG, Zur Hausen H. Unusual HPV types in oral warts in association with HIV infection. J Oral Pathol. 1988;17(9/10):4828.

9. Hanookai D, Nowzari H, Contreras A, Morrison JL, Slots J. Herpesviruses and periodontopathic bacteria in Trisomy 21 periodontitis. J Periodontol. 2000;71(3):376-84.

10. Kamma JJ, Contreras A, Slots J. Herpesviruses and periodontopathic bacteria in early-onset periodontitis. J Clin Periodontol. 2001;28(9):879-85.

11. Klemenca P, Skaleri U, Artnik B, Nogra P, Marin J. Prevalence of some herpesviruses in gingival crevicular fluid. J Clin Virol. 2005;34(2):147-52

12. Kubar A, Saygun I, Ozdemir A, Yapar M, Slots J. Real time polymerase chain reaction quantification of human Cytomegalovirus and Epstein-Barr virus in periodontal pockets and the adjacent gingiva of periodontitis lesions. J Periodontal Res. 2005;40(2):97-104.

13. Ling LJ, Ho CC, Wu CY, Chen YT, Hung SL. Association between human herpesviruses and the severity of periodontitis. J Periodontol. 2004;75(11):1479-85.

14. Michalowicz BS, Ronderos M, Camara-Silva R, Contreras A. Human herpesviruses and Porphyromonas gingivalis are associated with juvenile periodontitis. J Periodontol. 2000;71(6):981-8. 
15. Mombelli A, Meier C. On the symmetry of periodontal disease. J Clin Periodontol. 2001;28(8):741-5.

16. Nunn M. Understanding the etiology of periodontitis: an overview of periodontal risk factors. Periodontol 2000. 2003;32:11-3.

17. Parra B, Slots J. Detection of human viruses in periodontal pockets using polymerase chain reaction. Oral Microbiol Immunol. 1996;11(5):289-93.

18. Rones Y, Hochman N, Erlich J, Zakay Rones Z. Sensitivity of oral tissues to herpes simplex virus in vitro. J Periodontol. 1983;54(2):91-5.

19. Saygun I, Sahin S, Ozdemir A, Kurtis B, Yapar M, Kubar A et al. Detection of human viruses in patients with chronic periodontitis and the relationship between viruses and clinical parameters. J Periodontol. 2002;73(12):1437-43.

20. Saygun I, Yapar M, Ozdemir A, Kubar A, Slots J. Human cytomegalovirus and Epstein-Barr virus type 1 in periodontal abscesses. Oral Microbiol Immunol. 2004;19(2):83-7.

21. Sheiham A. Is the chemical prevention of gingivitis necessary to prevent severe periodontitis? Periodontol 2000. 1997;15:1524.
22. Slots J, Contreras A. Herpesviruses: a unifying causative factor in periodontitis? Oral Microbiol Immunol. 2000;15(5):27780.

23. Telenti A, Marshall WF, Smith TF. Detection of EpsteinBarr virus by polymerase chain reaction. J Clin Microbiol. 1990;28(10):2187-90.

24. Ting M, Contreras A, Slots J. Herpesviruses in localized juvenile periodontitis. J Periodontal Res. 2000;35(1):17-25.

25. Tonetti MS, Mombelli A. Early-Onset Periodontitis. Ann Periodontol. 1999;4(1):39-53.

26. Velazco CH, Coelho C, Salazar F, Contreras A, Slots J, Pacheco JJ. Microbiological features of Papillon-Lefevre syndrome periodontitis. J Clin Periodontol. 1999;26(9):622-7

27. Wara-Aswapati N, Boch JA, Auron PE. Activation of interleukin one beta gene transcription by Human cytomegalovirus: molecular mechanisms and relevance to periodontitis. Oral Microbiol Immunol. 2003;18(2):67-71. 